\title{
Article \\ Climatological Features of Squall Line at the Borneo Coastline during Southwest Monsoon
}

\author{
Fadila Jasmin Fakaruddin ${ }^{1,2}$, Najhan Azima Nawai ${ }^{1,2}$, Mahani Abllah ${ }^{1,2}$, Fredolin Tangang ${ }^{1}$ (D) \\ and Liew Juneng $1, *$ (i)
}

check for updates

Citation: Fakaruddin, F.J.; Nawai, N.A.; Abllah, M.; Tangang, F.; Juneng, L. Climatological Features of Squall Line at the Borneo Coastline during Southwest Monsoon. Atmosphere 2022, 13, 116. https://doi.org/ $10.3390 /$ atmos13010116 Academic Editor: Chunlei Liu

Received: 3 December 2021

Accepted: 5 January 2022

Published: 12 January 2022

Publisher's Note: MDPI stays neutral with regard to jurisdictional claims in published maps and institutional affiliations.

Copyright: (C) 2022 by the authors. Licensee MDPI, Basel, Switzerland. This article is an open access article distributed under the terms and conditions of the Creative Commons Attribution (CC BY) license (https:// creativecommons.org/licenses/by/ $4.0 /)$.
1 Department of Earth Sciences and Environment, Faculty of Science and Technology, Universiti Kebangsaan Malaysia, Bangi 43600, Malaysia; fadila@met.gov.my (F.J.F.); najhan@met.gov.my (N.A.N.); mahani@met.gov.my (M.A.); tangang@ukm.edu.my (F.T.)

2 Malaysian Meteorological Department, Petaling Jaya 46667, Malaysia

* Correspondence: juneng@ukm.edu.my; Tel.: +60-3-8921-5870

\begin{abstract}
Borneo Squall Line (BSL) is a disaster risk associated with intense rain and wind gust that affect the activities and residence near the northern coast of Borneo. Using 3-hourly rainfall from Tropical Rainfall Measuring Mission (TRMM) 3B42V7 during southwest monsoon season (MaySeptember) from 1998-2018, a total of 629 squall days were identified. Their monthly and annual average was 6 and 30 days, respectively, with July representing the month with the highest number of squall line days. BSL is frequently initiated during midnight/predawn and terminated in the morning. Composite analyses of BSL days using the daily winds from the European Centre for Medium-Range Weather Forecasts (ECMWF) ERA-Interim revealed that lower tropospheric wind convergence is a crucial controlling factor for BSL formation. The position of the monsoon trough closer to the equatorial South China Sea (SCS), and strong westerly and south-westerly winds played an important role in creating this wind convergence region. Analyses of tropical cyclone (TC) data from the Regional Specialized Meteorological Centre (RSMC), Tokyo showed that nearly 72\% of BSL occurred with the presence of TC. Spectral analysis exhibited prominent frequencies mainly in the 3-4- and 6-year time scale, which likely reflected the influence of interannual modulation of El-Niño Southern Oscillation (ENSO). Correlation coefficient between squall days and Sea Surface Temperature (SST) anomalies indicated that BSL increased after La-Niña events. This study is expected to have implications for real-time squall line forecasting in Malaysia and contributes toward a better understanding of BSL.
\end{abstract}

Keywords: squall line; thunderstorm; Malaysia; Borneo; southwest monsoon; summer monsoon

\section{Introduction}

Squall line is a type of mesoscale convective system (MCS), characterized by a group of multicell thunderstorm clouds in a single line. It exhibits a larger spatial dimension and longer lifetime, with rapid increase in wind speed (gusting) and intense precipitation that extends well beyond a single-cell thunderstorm [1]. This can lead to significant damage that is rare in individual cells. Squall line can form via a variety of mechanisms and all of them correspond to warm, moist air at low levels. These conditions include the sea and land breeze circulations, barotropic instability and mesoscale changes in high-level vorticity [2]. Squall line on radar observation consists of convective rain band leading edge with a width of several of tens of kilometers and a length of several hundred kilometers followed by a wide area of stratiform rainfall. In the satellite observation, squall line usually appeared as a small dot at the early stage of formation, then expands and begins to merge, forming a continuous large cloud line [3].

A lot of studies have been conducted to examine the formation of squall line in tropical regions. The authors of [3] studied the structure and dynamics of the tropical squall line 
system and discovered that the downpour of heavy precipitation below the sloping updraft of the squall line system encompassed a convective-scale downdraft in the heavy rain zone, which spread out at low levels, while the precipitation from the anvil cloud was in stratiform type. The study of [4] further broadened the concept of the squall line to include these two regions; a convective squall line region (the leading edge of the system) and an anvil region (stratiform) which showed different updraft/downdraft motions. They emphasized that the squall line region was characterized by boundary layer convergence, which fed deep convection updrafts. On the other hand, the anvil region was characterized by mid-level convergence, which fed up an updraft in the anvil cloud and downdraft beneath the anvil. This study formed the basis of other studies on the structure of the tropical squall line (e.g., [5-9]). As revealed by [2,8,9], the development of tropical squall line was mostly attributed to low-level wind convergence due to the lack of a frontal system here and less frequent changes in the air mass.

In Malaysia, squall lines are commonly observed from May to September along the Straits of Malacca and Borneo Island, mainly over Sarawak and Sabah coastline facing the South China Sea (SCS). The squall lines formations along the Straits of Malacca, commonly known as Sumatra Squall Line (SSL) have been well studied by [10-14]. The formation of SSL is found to be influenced by a few mechanisms. A semi-idealized numerical analysis by [14] found that the SSL is formed in a condition of low-level convergence, where the northerly flows from high reliefs along west Sumatra converge into the strait with the southwest monsoonal flows from the south. Its formation is also enhanced by the convergence resulting from colliding land breezes from the west and the east coast of the Straits of Malacca. A diurnal cycle could also be one of the factors that encourage the formation of SSL. The diurnal cycle and topography of the mountain range over Sumatra resulted in thermally and convectively induced local circulations that produced nocturnal rainfall over the west coast of Sumatra, thus triggered the formation of SSL [13]. Most of SSL's initial thunderstorms developed over the straits during the night-time and had grown dramatically in size while maintained their intensity during midnight. They then propagated east towards the west coast of Peninsular Malaysia in early morning and reached the maximum intensity and extended greatly in size as the systems moved offshore [11].

On the contrary, the Borneo Squall Line (BSL) over the Borneo coastline is less well studied despite its yearly occurrences. A few studies are reporting the structure of BSL formation, which is attained through the studies of daily and annual rainfall cycles around Borneo (e.g., [15-17]). The study of [17] found that during July to August, the adjacent ocean around Southeast Asia showed enhanced convective activity in the local morning hours with the maximum at around 0600 to 0900 Local Time (LT), which indicates a similar formation of BSL over the coastal regions of Borneo. This condition was associated with the interaction between the land-sea breeze circulation and the large-scale monsoonal flow. "Local Time" refers to Malaysia local time, $8 \mathrm{~h}(\mathrm{~h})$ ahead of UTC time (UTC $+8 \mathrm{~h})$. The authors of [15] also revealed the same features, where convective systems developed in the SCS region and moving into the coastal areas of Borneo that caused heavy rains from midnight to morning. The study of [16] in turn found that at the coastal areas of Borneo, the midnight-to-morning rainfall peak was apparent at the central and northern region, which indicated the features of BSL formation.

Due to limited studies on BSL, therefore, their features and formation environments are relatively unknown. Hence, this study aims at documenting general features of BSL including their temporal and spatial climatology distributions and durations, as well as the environmental features that lead to their formations. Forecasting BSLs is considered important but it is challenging due to their rapid development and movement. Besides, they produced intense period of heavy rain and wind gust that can give an impact on coastal activities such as fishing, oil rig, aviation, and residential near the coastal. Understanding BSLs is crucial to protect commercial shipping, industries, and properties from weather- 
related losses. Thus, this study is expected to have positive implications for real-time squall line forecasting in Malaysia and contributes to the understanding of how BSL is formed.

\section{Experiments}

\subsection{Study Area}

The study area is located at Borneo Island, the largest island in the Southeast Asia region (Figure 1), which is occupied by three nations i.e., Malaysia, Indonesia, and Brunei. However, in this study, the BSL events considered are limited to those bounded within the domain of $1.0-8.0^{\circ} \mathrm{N}, 109.0-117.0^{\circ} \mathrm{E}$ (Box A), and propagating towards the coastlines of Malaysian's states of Sarawak and Sabah and Brunei (Figure 1).

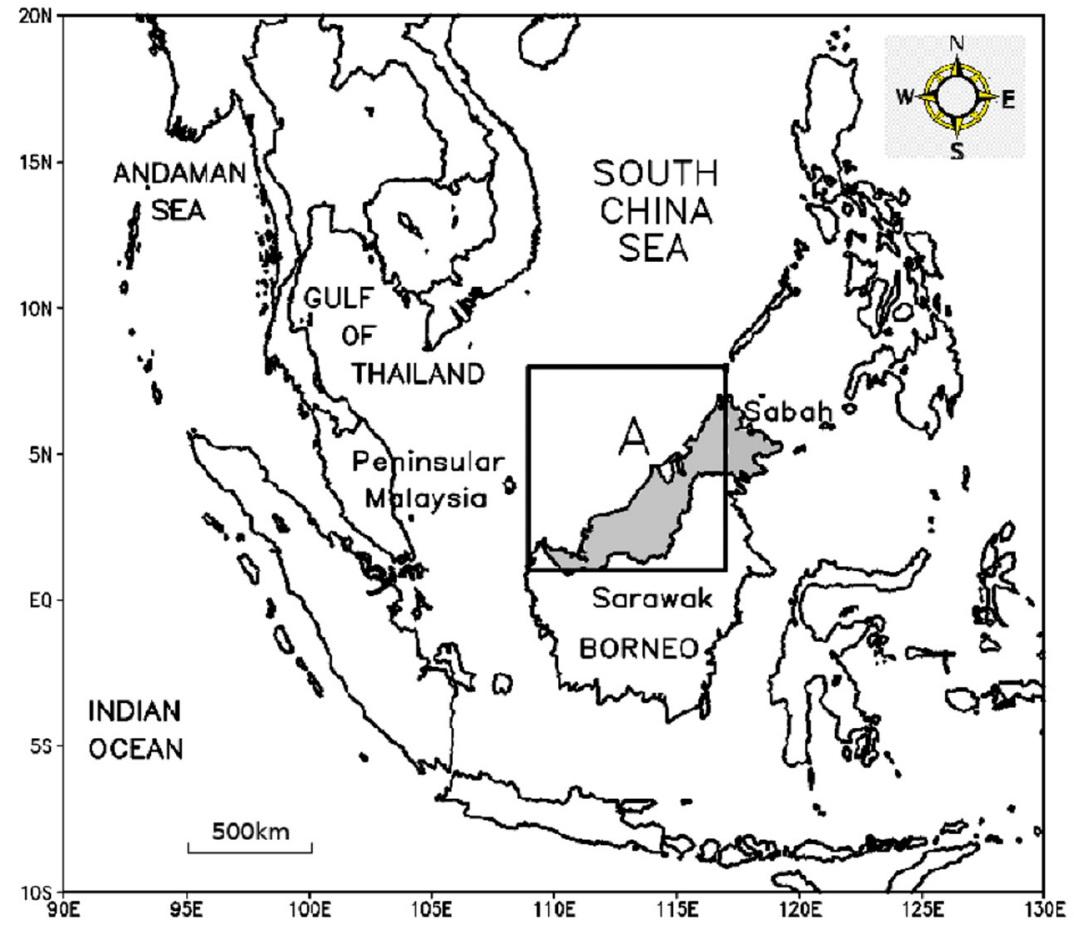

Figure 1. Topography map of the study area. Box A indicates the region where the events are selected, bounded from $1.0-8.0^{\circ} \mathrm{N}, 109.0-117.0^{\circ}$ E. It covers the events that propagate towards Sarawak and Sabah coastlines. Sarawak and Sabah are shaded in grey.

\subsection{Identify BSL from Rainfall Data}

This study utilized the 3-hourly accumulated rainfall data from Tropical Rainfall Measuring Mission (TRMM) Multi-satellite Precipitation Analysis (TMPA) 3B42V7 spanning 21-years of Southwest Monsoon (SWM) season (1998-2018, May-September) in identifying the BSL events (hereafter referred to as TRMM-3B42V7). This product was obtained from the Goddard Earth Sciences Data and Information Services Center (GES DISC) website, https:/ / disc.gsfc.nasa.gov, accessed on 1 December 2021. The product output was based on two different sets of sensors: microwave and infrared (IR) estimates with gauge adjustment [18]. TRMM-3B42V7 is appropriate for the detection of squall line cloud observation in the coastal region of Borneo as precipitation estimates over tropical oceans are usually carried out using passive infrared (IR) measurements of cloud-top brightness temperature from geostationary satellites to infer deep convection positions [19]. Compared with spatially sparse gauge observations, TRMM-3B42V7 rainfall data have a significant advantage due to their greater observation density, particularly over ocean areas [20]. In addition, by using TRMM-3B42V7, it is easier to identify MCS like squall line by its cold cloud shield, which is commonly larger than the area of convection and often is more contiguous [21]. Furthermore, the validation of TRMM-3B42V7 over Malaysia and the neighboring regions also showed high consistency with ground observation [22-27]. A recent study by [28] 
showed that TRMM-3B42V7 is a reliable gridded precipitation product in Malaysia. Most of the previous studies focused on the June-July-August (JJA) period to represent the SWM season. Instead, the May to September period was chosen in the current study as to extend the analysis to include the early phase and the later phase (onset and withdrawal) of the SWM season to see the differences in the variability of BSL frequency.

Current study uses the cloud classification based on [24,29-34]. These studies adopted the generic term for organized convective complexes as the cloud systems that occur in connection with an ensemble of thunderstorms produces a contiguous precipitation area $100 \mathrm{~km}$ or more in at least one direction. In the current study, a BSL is defined as an organized eastward-moving line of contiguous precipitation area that formed in the SCS, which then propagates towards the Borneo coastline. Using plotting of 3-hourly rainfall data of TRMM-3B42V7, the observation focused on the precipitation that scattered and then merged, forming a line of thunderstorm clouds at the Borneo coastline. The daily rainfall data from the same dataset was also used to confirm the occurrences of heavy rainfall at the Borneo coastline on the event's date. In addition, this study also made validation with the radar data from the Malaysian Meteorological Department (MMD) for some of the detected events, to make sure that the events were the squall line events. However, this study was unable to validate with radar data for all detected BSL events due to the difficulty of obtaining the radar data with sufficient observations for the study period. Furthermore, MMD has sparse radar data coverage with only four radar stations in Sabah and Sarawak (Borneo), and the observation of these radar is sometimes interrupted for certain reasons. There are other definitions involving pressure, winds and other atmospheric parameters in identifying the squall lines as described in the above-stated previous studies. However, since the objective of this study does not include microphysical processes such as observations on the dynamic and thermodynamic structures of the squall line, thus the observations are made only based on the cloud structure through satellite or radar observations. That is why the rainfall data is used in the observations. A similar approach has also been implemented in several studies on the observations of the squall line, as such conducted in squall line study in the Straits of Malacca and Sumatra $[2,10,11,13,35,36]$.

For each detected BSL event, the initiation time is considered at the hour the leading edge of the line of thunderstorms started entering Borneo waters denoted in Box A of Figure $1\left(1.0-8.0^{\circ} \mathrm{N}, 109.0-117.0^{\circ} \mathrm{E}\right)$. The landfall time is the hour when the leading edge of thunderstorms reach Borneo, while the termination time is the hour when the line of thunderstorms made landfall at the coastline and dissipated in the next observation. BSL day is determined based on its initiation time. Based on the diurnal variation of BSL, the life cycle of a typical squall, such as its initiation, landfall and termination time, as well as its annual and monthly frequency, were analyzed to create BSL's spatial and temporal climatology.

\subsection{Composite of Wind and Rainfall Data}

The composite of daily $925 \mathrm{hPa}$ winds and rainfall were created to investigate the characteristics of BSL. The analyses involved the identification of BSL days and enumeration into monthly distribution for both rainfall and $925 \mathrm{hPa}$ winds. The daily wind is available from 1 January 1979, until the present and has a spatial resolution of $0.75^{\circ} \times 0.75^{\circ}$. It was obtained from the European Centre for Medium-Range Weather Forecasts (ECMWF) ERAInterim dataset [37]. The daily rainfall data was obtained from the TRMM-3B42V7 dataset.

\subsection{Tropical Cyclone (TC) Data}

The TC data from the Regional Specialized Meteorological Centre (RSMC), Tokyo operationalized under the Japan Meteorological Agency (JMA), was applied to investigate the relationship between BSL and TC. The dataset is available from 1 January 1951, until the present day, and consists of the TC data in the western North Pacific Ocean (WNP) region from $0-50^{\circ} \mathrm{N}, 100-180^{\circ} \mathrm{E}$. The analyses involved the identification of BSL days 
that occurred with the presence of TC over the WNP region. The monthly anomalous composites of winds during BSL in the presence of TCs were computed from 1998 to 2018 (May-September).

\subsection{Spectral Analysis and Correlation Analysis}

The spectral and correlation analyses were conducted to examine the relationship between BSL and El-Niño Southern Oscillation (ENSO). The spectral analysis was applied to the BSL days of each year to detect the inter-variation in BSL occurrence. Meanwhile, the correlation analysis between BSL days and the Sea Surface Temperature (SST) anomalies $\left({ }^{\circ} \mathrm{C}\right)$ of National Centers for Environmental Prediction/National Center for Atmospheric Research (NCEP/NCAR) reanalysis [38] was made online using the Interactive Climate Analysis and Plotting Tools from National Oceanic and Atmospheric Administration Physical Sciences Laboratory (NOAA PSL) through their website https: / psl.noaa.gov /, accessed on 1 December 2021. Their anomalies data are computed from the 1981-2010 base period monthly means. The correlation analysis was carried out from preceding seasons, i.e., January-March, March-May, and May-July to observe the influence of ENSO on the BSL occurrences. To ensure that there is a significant relationship between the BSL and ENSO, the correlation analysis between the monthly frequency (day) of BSL and the Multivariate ENSO Index Version 2 (MEI.v2) from NOAA PSL is extended using the statistical correlation method. By considering the relatively small sample size in this study, i.e., a total period of 21 years (1998-2018, May-September), it is not guaranteed that the sample is characterized by a Gaussian distribution. Therefore, the non-parametric Kendall's Rank correlation and the Wilcoxon Rank Sum test are respectively used to assess the correlation coefficient and their statistical significance. Such tests are widely used to determine the relationship between non-parametric atmospheric and ocean variables in previous studies [39-46]. This study used MEI.v2 values in the December-JanuaryFebruary (DJF) period to represent the ENSO period. This period was chosen because it has been acknowledged as the peak intensity of ENSO $[47,48]$. This period has also been adopted in previous studies related to ENSO [47-58].

\section{Results and Discussion}

\subsection{Spatial and Temporal Climatology of BSL}

Figure 2 shows the formation and propagation of a BSL from 26 June 2016 (2300 LT) until 27 June 2016 (1400 LT). The BSL clouds can be identified by several thunderstorm clouds that scatter over the offshore of Borneo. It shows a typical squall beginning as an initial thunderstorm over the coastal area of Borneo (Figure 2a). They expand and begin to merge, forming an organized line of thunderstorms (Figure 2b). Following the westerly winds, this line of thunderstorms propagates eastward towards the coastline of Borneo (Figure 2c). As shown in the observation, BSL intensified and reached its maximum intensity on 27 June 2016 (0800 LT) upon arrival at the shoreline (Figure 2d). The BSL clouds are gradually dissipating as their cloud bands dissolve and their intensity weakens from 1100 LT (Figure 2e). As observed on the next 3-h observation (1400 LT), the BSL clouds are no longer visible, signaling the dissipation of BSL (Figure 2f). The dissipation of BSL clouds can be confirmed when this thunderstorm line is no longer visible on the observation. It is important to note that this example shown a typical formation and propagation of BSL events that being observed throughout the study period (it applies to most cases). However, it does not imply for all cases as they not moving at the same speed. Moreover, some of the cases may also occur at daytime. 


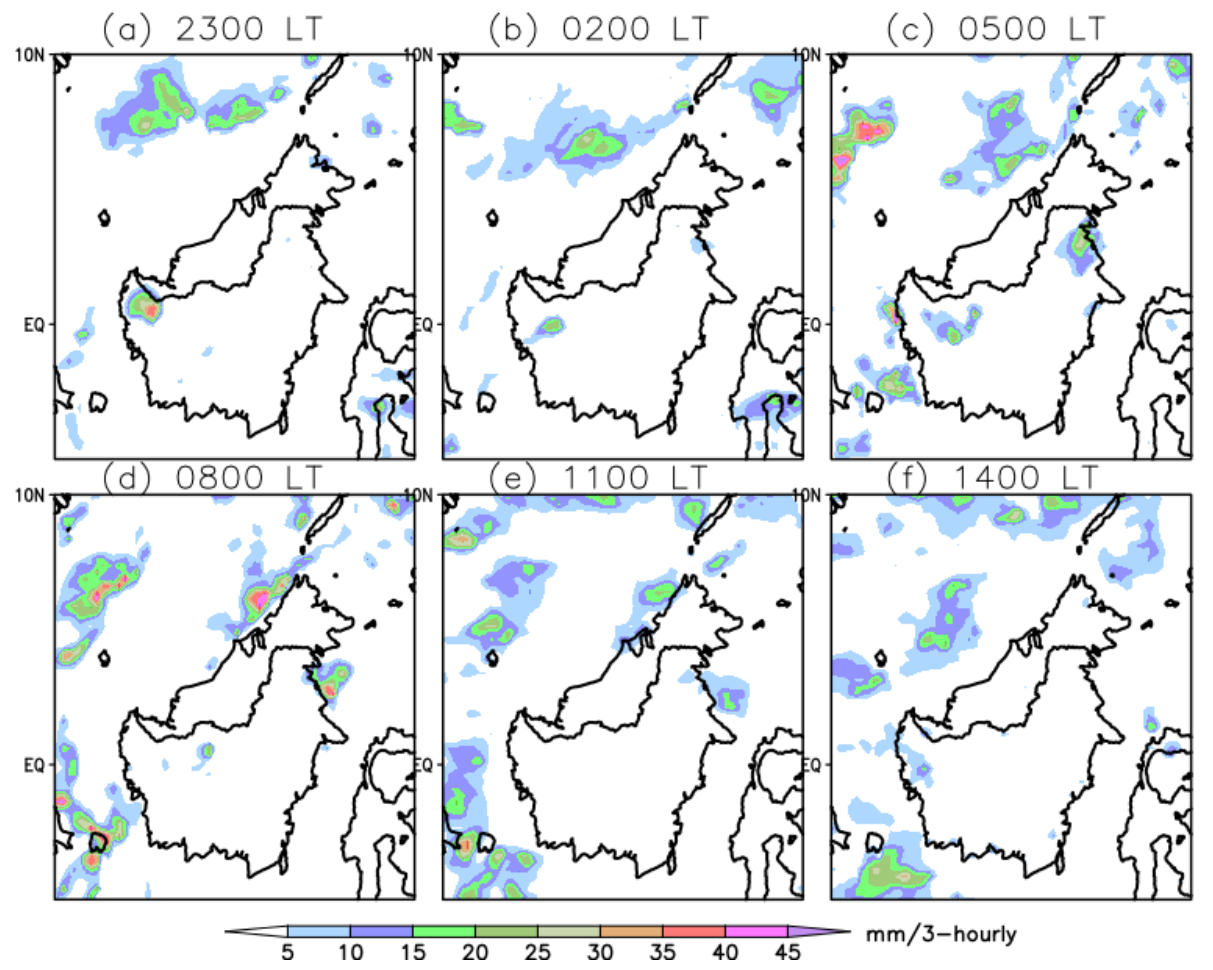

Figure 2. The formation and propagation of a BSL from 26 June 2016 (2300 LT) until 27 June 2016 (1400 LT). (a) It shows a typical squall beginning as an initial thunderstorm over the coastal area of Borneo, (b) they expand and begin to merge, forming an organized line of thunderstorms, (c) following the westerly winds, this line of thunderstorms propagates eastward towards the coastline of Borneo, (d) BSL has intensified and reached its maximum intensity on 27 June 2016 (0800 LT) upon arrival at the shoreline, (e) BSL clouds are gradually dissipating as their cloud bands dissolve and their intensity weakens from 27 June 2016 (1100 LT), (f) as observed on the next 3-h observation 27 June 2016 (1400 LT), the BSL clouds are no longer visible, signaling the dissipation of BSL.

One of the most noticeable features is that BSL forms over the ocean and propagates eastward towards the coastline. The movement of the squall line usually follows the surface winds $[1,2]$. The propagation of BSL does not correspond to the wind direction, i.e., southwesterly and parallel to the coastline of Borneo. This condition is believed to be due to the role of land breeze and sea breeze that play significant role in the formation of inland rainfall at daytime and developing offshore rainfall at night until morning time [13,15-17,59-66].

During night-time, air over land cools more rapidly than air over the sea. The temperature contrast between the land and the sea along the western Borneo coast occurs at night and in the early morning, with cooler air present over the island and relatively warmer air located over the sea. A strong offshore flow occurs over the sea adjacent to the western coast, which creates an intensive wind convergence at the low-levels, and initiates convection offshore near the coast at late night and early morning. Vertical and horizontal extent of the offshore flow is known to be greater than the typical land breezes [59]. Thus, these strong offshore flows are believed to be the push-factor that contribute to the eastward movement of BSL that occurs over the SCS, pulling clouds toward the coastline of Borneo.

A total of 629 squall line days were identified over the Borneo coastline from 1998 to 2018 (May-September) as presented in terms of average frequency (day) of BSL per month in Figure 3. The average of BSL increases from 4.4 days in May to 6.7 days in June and 7.2 days in July. It decreases to 4.9 days in August, then increases again to 6.8 days in September with an overall monthly mean of $\sim 6$ days. The frequency distribution of BSL (day) are dependent on the position of the monsoon trough and the strength- 
ening of the westerly winds in the SCS. These conditions will be discussed further in Sections 3.2 and 3.3 , respectively.

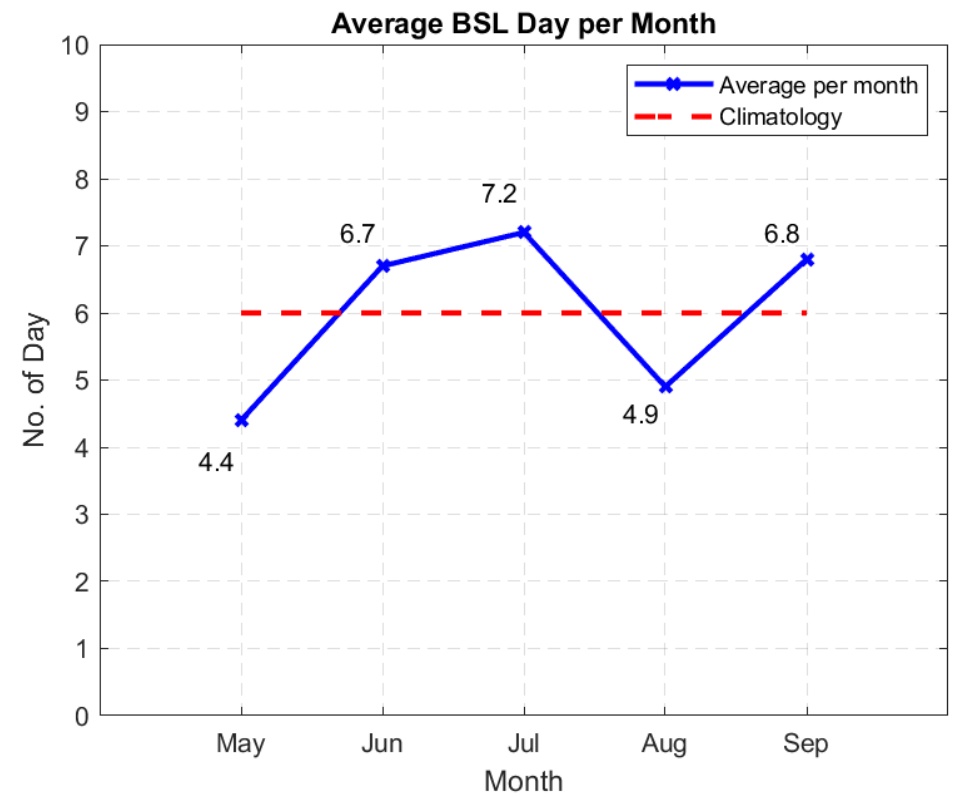

Figure 3. Average frequency (day) of BSL per month.

Figure 4 depicts the total annual frequency (day) of BSL from the year 1998 to 2018. The maximum and minimum occurrences were recorded in the years 2009 (49 days) and 1998 (12 days), respectively, with an average of $\sim 30$ days of occurrence per year. Interannual variation is clearly depicted with the number of occurrences in 2008, 2009, 2012, 2013, and 2014 are above average, while below-average years are in 1998, 1999, 2010, and 2015. These interannual variations appeared to be related to the ENSO. It is noted that the above-average occurrences are recorded after the La-Niña years, while those below-average are recorded after the El-Niño years. In addition, the increasing and decreasing numbers of occurrences are also related to the intensity of El-Niño and La-Niña. It is revealed that the aboveaverage occurrences are evidenced after the moderate La-Niña, which is in 2007/2008 and 2010/2011. On the other hand, the below-average occurrences are evidenced after the strong and moderate El-Niño, which is in 1997/1998, 2014/2015 (strong) and 2009/2010 (moderate), respectively. Considering DJF period, the years of El-Niño and La-Niña from 1998 to 2012 are determined based on [67], while the remaining years are determined based on [68]. DJF describes the strongest ENSO period, therefore, it presumes to reflect the actual influence of ENSO in regulating the moisture transport in the atmosphere [58].

The above analysis shows that the interannual variation of BSL occurrences appeared to be related to ENSO. This condition occurs due to the regional transport of moisture and moisture variations, which are modulated by the regional interaction between the atmosphere and the ocean, that develop according to the El-Niño and La-Niña phases. As moisture is crucial for the precipitation process, the precipitation extremes during El-Niño and La-Niña are likely to be influenced by the regional atmosphere and the ocean interaction $[55,58,67]$. Moreover, the role of El-Niño and La-Niña in modulating the variability of rainfall and contributing to the extreme weather events in Malaysia are well documented $[49,51,53,58,67]$. Generally, overall total precipitation in Malaysia, including Borneo, decreased during the El-Niño years and increased during the La-Niña years [67,69]. In addition, the dry and wet precipitation extreme events are also shown to be influenced by the intensity of El-Niño and La-Niña [67]. Hence, much like the rainfall distributions, BSL occurrences presumably are strongly influenced by El-Niño and La-Niña. The role of ENSO in influencing the BSL occurrences will be discussed further in Section 3.4. 


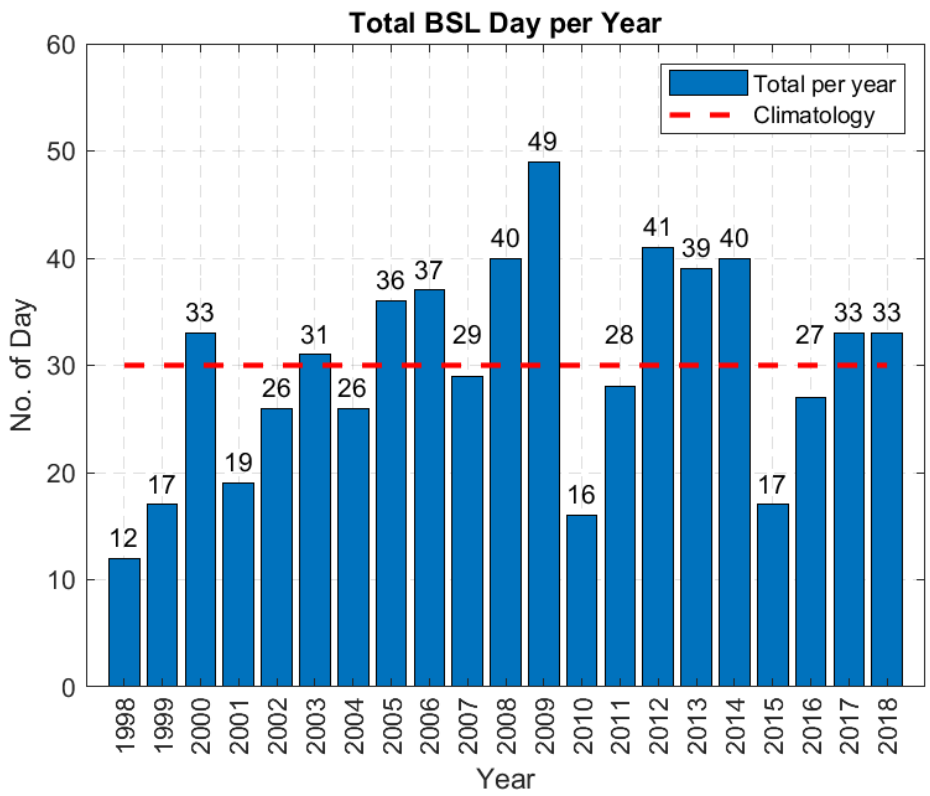

Figure 4. Total annual frequency (day) of BSL from the year 1998 to 2018.

Figure 5 displays the averaged BSL initiation, termination and landfall times. The distribution suggests that the initiation, landfall and termination time is at 2100 UTC, 0000 UTC and 0300 UTC, respectively. As the frequencies are based on 3-hourly accumulated rainfall data, it is noted that BSL frequently initiated between 2000-2200 UTC, landfall between 2300-0100 UTC and terminated between 0200-0400 UTC. This indicates that BSL events mostly initiated during midnight/predawn and terminated in the morning, and therefore its formation and development mechanism are also likely to be influenced by the diurnal cycle. The diurnal cycle is one of the many controlling factors dictating the formation, propagation and dissipation of the SSL in the Straits of Malacca [11,12,14]. This condition was found to occur during the formation of the BSL as well. In the night-time, the land breezes from the Borneo landmass blow perpendicular to the coast. During this time, the land breezes are intense and much higher, while the sea breezes are weaker and shallower. Convective scale updrafts and outflows act to enhance the land breezes. The upward motion thus produced in the land breeze circulations coincidentally coupled with convective updrafts, creating much stronger and deeper vertical transport [14]. Besides, the coastline direction over the Borneo which is parallel to the low-level prevailing wind enhances the convective vertical development [15]. This may lead to more convergences between lower winds and the land breezes that are perpendicular to the coast and yield deeper shear. As BSL propagates eastward toward the coastline, it interacts with this shear to build deeper convection. Moreover, when reaching the land area, a weak shear is forced to occur due to the blocked convection by the land terrain of the island (poor lifting mechanisms) and thus, the BSL is ceased. The heat also suppresses the convection as the sun rises in the morning [14].

\subsection{Synoptic Features during BSL}

The seasonal composite of daily wind and rainfall during all BSL and non-BSL days from May to September are shown in Figures 6 and 7, respectively. In Figure 6, the blue to red shaded area indicates stronger wind speed, while the monsoon trough is denoted by a black, thick-dashed line. During BSL (Figure 6a), the Northern Hemisphere monsoon trough is located closer to the equatorial SCS $\left(10-20^{\circ} \mathrm{N}\right)$ compared to Non-BSL (Figure $6 \mathrm{~b}$ ). With the presence of the monsoon trough near the equatorial SCS, westerly winds from the Indian Ocean (IO) trap within this trough. At the same time, the monsoon trough in the southern hemisphere occurs between $0^{\circ}$ to $5^{\circ} \mathrm{S}$. This trough creates intrusion of the south-westerly winds into the SCS through Sumatra, Peninsular Malaysia, and Borneo 
Island terrain, thus enhancing the wind-terrain interactions on the west coast of Borneo [70]. This condition is known as the cross-equatorial flow. Furthermore, these cross-equatorial flows and the westerly winds give rise to a broad-scale belt of convergence in the equatorial SCS. The wind speed also plays an important role in the formation of BSL. It is noted that stronger westerly winds speed existed during BSL (Figure 6a) compared to non-BSL (Figure 6b). The impact of a broad-scale belt of wind convergence in the equatorial SCS is evident as intense rainfall concentrated over the SCS, northern region of the Borneo Island and eastern region of the Philippines during BSL (Figure 7a) compared to non-BSL (Figure 7b), a typical condition (dry weather) during the SWM season in Malaysia.

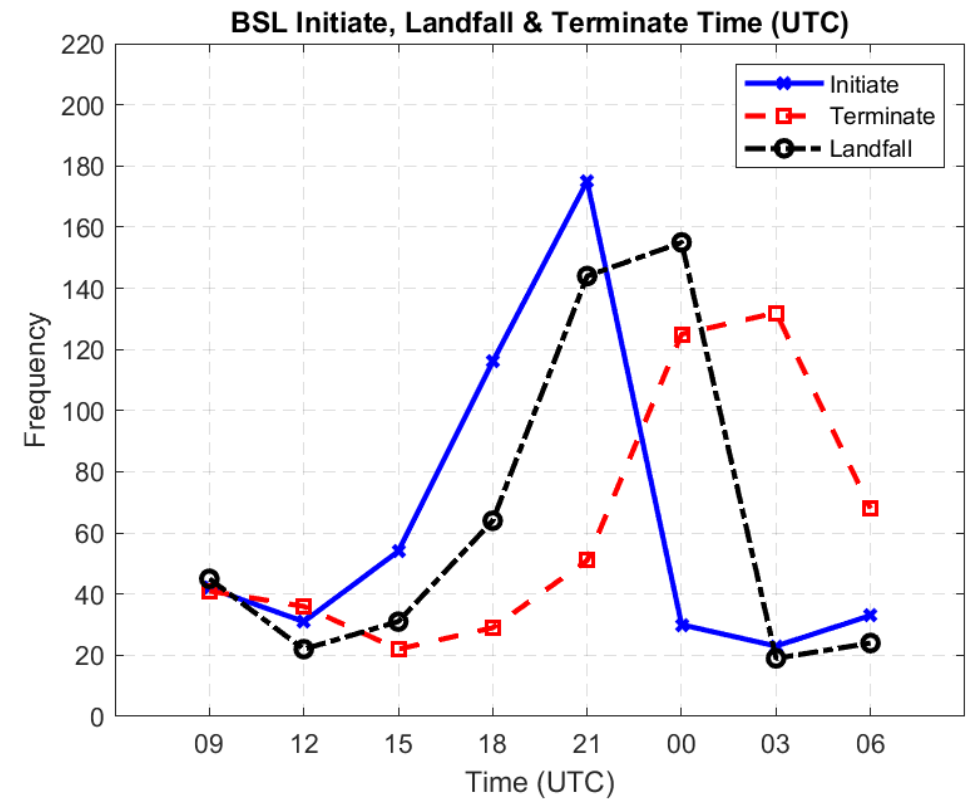

Figure 5. BSL initiation, landfall and termination times. The Time-Frequency series are based on 3-hourly accumulated rainfall data.

(a) BSL

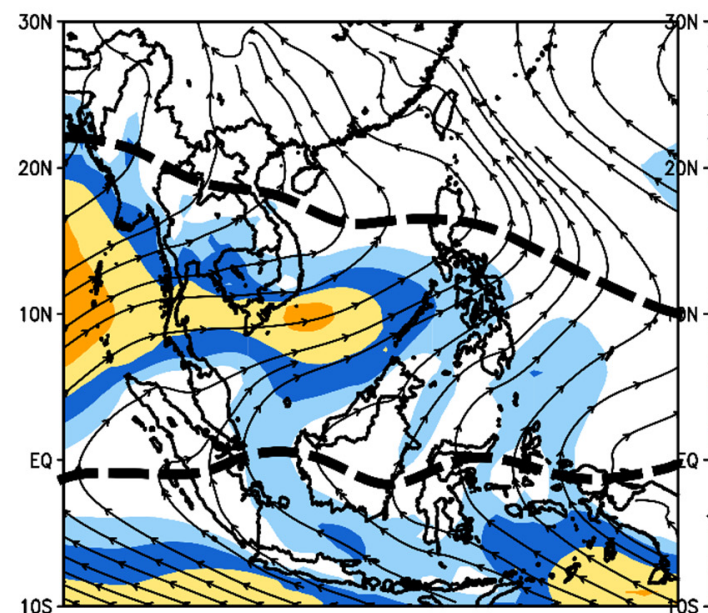

(b) NoBSL

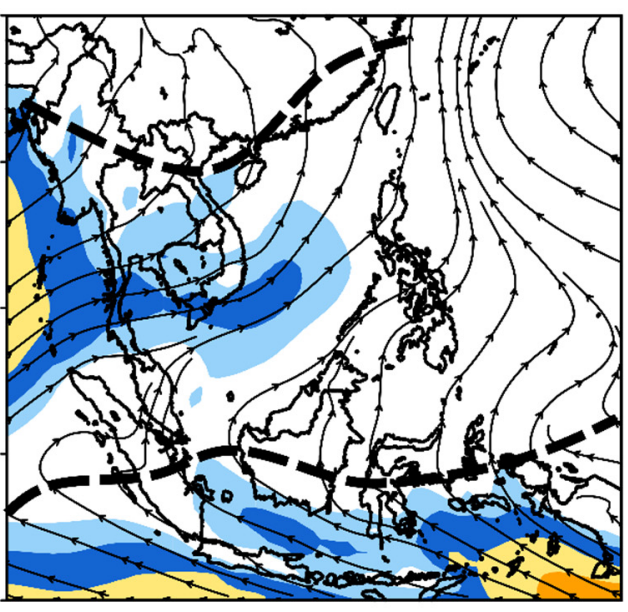

$\mathrm{m} / \mathrm{s}$

Figure 6. Composite 925-hPa daily wind streamline charts of all collected (a) BSL days; and (b) NonBSL days from the year 1998 to 2018 (May-September). Blue to red shaded area indicates stronger wind speed, while monsoon trough is denoted by a black, thick-dashed line. 
(a) BSL

(b) NoBSL

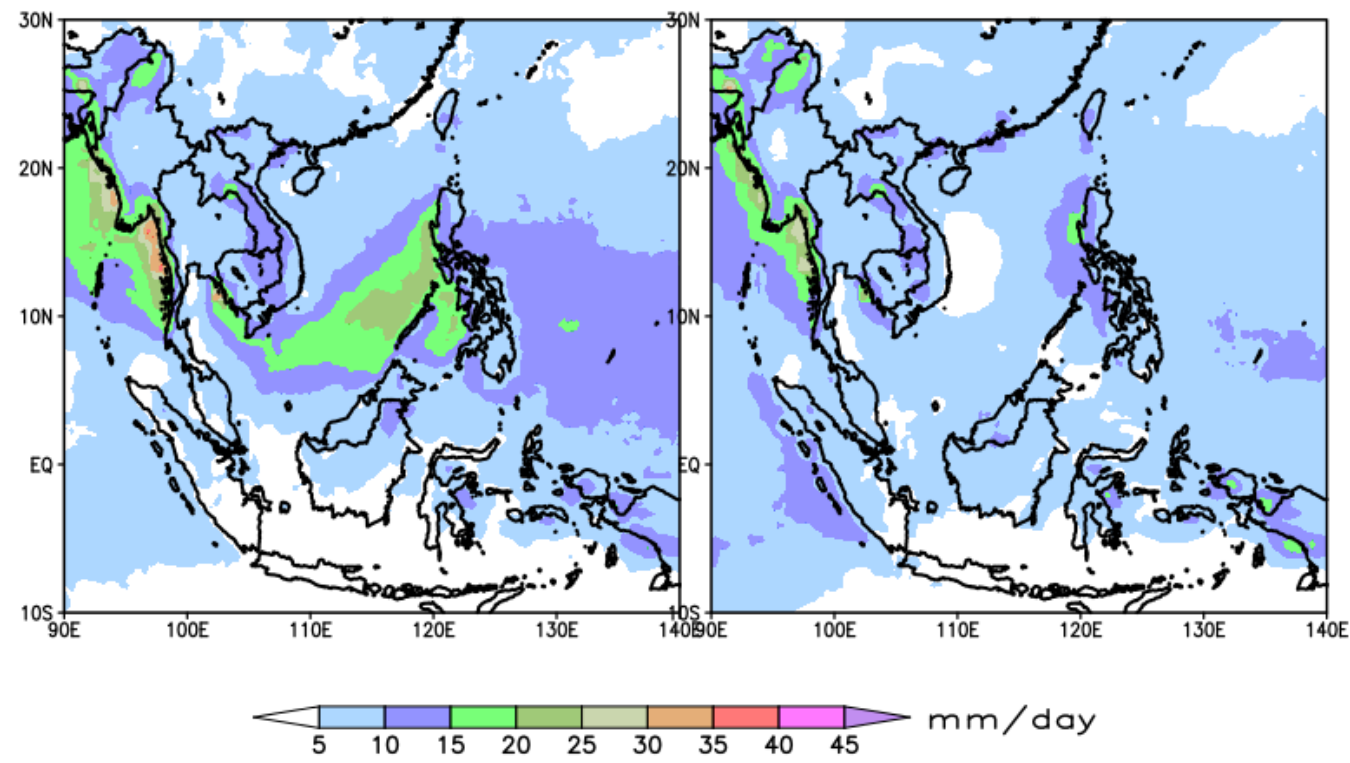

Figure 7. Composite daily rainfall charts of all collected (a) BSL days; and (b) non-BSL days from the year 1998 to 2018 (May-September). Green to red shaded area indicates heavier (intense) rainfall.

The monthly composite of daily wind during all BSL days in May, June, July, August, and September are analyzed in Figure 8a-e, respectively to investigate the variations of BSL frequency and their synoptic features in those months. The averaged frequency (day) of BSL per month is indicated in the bracket at the upper corner of each panel. The blue to red shaded area indicates stronger wind speed, while the monsoon trough is denoted by a black, thick-dashed line. Generally, from May to July (Figure 8a-c), the Northern Hemisphere monsoon trough is observed near the equatorial SCS $\left(10-20^{\circ} \mathrm{N}\right)$. The Southern Hemisphere monsoon trough is also clearly visible between $0^{\circ}$ to $5^{\circ} \mathrm{S}$. The westerly winds speed also gradually increases through this period, giving rise to a broad-scale belt of wind speed convergence in the equatorial SCS. This condition encourages the development of intense rainfall, thus promoting the BSL initiation and causing the BSL frequency to increase significantly during the period.

The northward migration of the monsoon trough in the northern hemisphere is noticeable in August (Figure 8d), where it is located slightly to the north than its original position in July. It is now located at $15^{\circ} \mathrm{N}$ to $25^{\circ} \mathrm{N}$ between the northern region of the Philippines to the northern Indochina region nearly in the horizontal direction. The northward migration of the trough results in extensive intrusion of the south-westerly winds to the SCS. This condition also coincides with the strengthening of $925-\mathrm{hPa}$ westerly winds. The westerly winds now extended further to the east across the SCS to the WNP. The convergence region now develops in the area slightly to the northern region of SCS, leading to a decrease of BSL frequency in August.

The westward intrusion of the western North Pacific subtropical high (WNPSH) in the northern SCS region indicates that the Asian summer monsoon gradually coming to the end $[71,72]$. This condition results in the weakening and retreat of the south-westerly winds over the northern IO and the SCS. It is evident in September when the westerly winds from the IO and cross-equatorial flow begin to weaken as they penetrate the SCS (Figure 8e). However, the cyclonic vortices are prominent during this period over the offshore of Vietnam and the central Philippines causing the trough closer to equatorial SCS. With the southward movement of the monsoon trough, the convergence area develops again over the equatorial SCS leading to the increase in the BSL occurrences. 

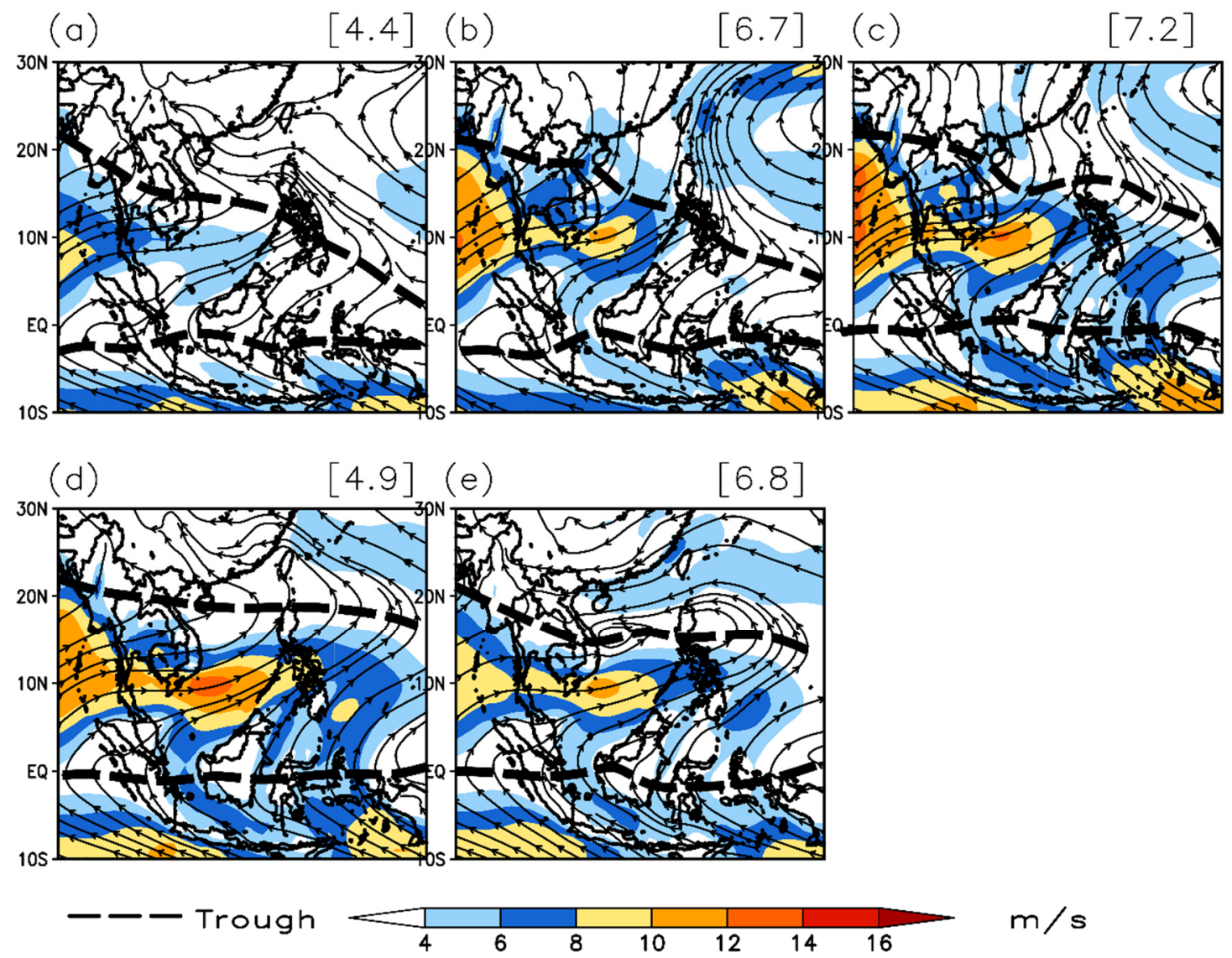

Figure 8. Composite 925-hPa daily wind streamline charts of all collected BSL days in (a) May, (b) June, (c) July, (d) August; and (e) September from the year 1998 to 2018. The average frequency (day) of BSL per month is indicated in the bracket at the upper corner of each panel. Blue to red shaded area indicates stronger wind speed, while monsoon trough is denoted by a black, thick-dashed line.

The analysis highlights that lower tropospheric wind convergence is the controlling factor of BSL formation. The position of the monsoon trough closer to the equatorial SCS and strong westerly component played an important role in creating this wind convergence region (due to directional and speed convergence). Consistent with previous studies, the low-level wind convergence is the most contributing factor to the development of squall line in the tropics $[2-4,8,9]$. The same condition is also revealed in BSL formation. The low-level convergence in the equatorial SCS became a major factor in the formation of BSL. Low-level convergence is a lifting mechanism that increases the lifting of air masses in an area and creates a moist environment, while the wind shear allows air in the low-level to overcome low-level convective inhibition [73]. The region that has the greatest combination of these lifting mechanisms are often the location that severe thunderstorms first develop. As the squall lines need extensive air aloft to maintain their life cycles, thus, they frequently develop in the moist environment over the low-level [3,73].

The result also reveals that the frequency of BSL shows a significant increase and decrease from July to September due to the movement of the trough slightly to the north during August as compared to its original position in July, then it moves again to the south close to the Borneo region during September. The higher frequency of BSL occurred with the position of the monsoon trough being closer to the equatorial SCS $\left(10-20^{\circ} \mathrm{N}\right)$. On the other hand, a decrease in the frequency of BSL occurred when the position of the monsoon trough moves slightly to the north. This can be explained by [74] who described the monsoon trough as part of the Intertropical Convergence Zone (ITCZ), which is commonly described as a convergence zone between the wind patterns of the Southern Hemisphere and the Northern Hemisphere. Right along its axis, this wind convergence zone produces heavy 
rainfall that dominates the peak of the rainy season in certain locations. As it moves to the north/south or passes poleward of a location, hot and dry conditions develop. Due to this condition, the monsoon trough plays a major role in creating heavy rainfall episodes during the monsoonal season in the western Pacific, especially in the Asian region [74]. In addition, as the monsoon trough provides an environment of large vorticity, strong cyclonic vortexes, and tropical cyclones over the WNP often form in the vicinity of the monsoon trough [75]. It is also found that $70-80 \%$ of WNP tropical cyclones form within the monsoon trough in all months, except July and August, when the number of tropical cyclone formations outside the monsoon trough grows dramatically, mostly on its poleward side [76]. These conditions conducive to more troughs develop over the north of the equatorial SCS. Therefore, the movement of the trough to the north during August can be caused by the development of WNP TCs to be more to the north of SCS, thus presumably causing significant decreases of BSL. Accordingly, as the movement of monsoon trough plays a major role in influencing the rainfall distribution in Asia and Malaysia in general, therefore, this condition tends to affect the frequency of BSL events as well.

\subsection{The Relationship between TC and BSL}

The WNP is the basin with the most active TC activity in the world, with about $30 \%$ of the global total cyclogenesis [77]. Although TCs may form throughout the year in WNP, most TCs occur from June through September, with a peak in August $[77,78]$. The average number of TC per year in the WNP since 1981 is 26 [79]. One of the striking features due to the formation of TCs in the WNP is that TCs resulted in strong westerly winds to the SCS [80]. Given that the BSL has significantly occurred in the condition of stronger westerly winds, this section is designed to understand whether the favorable condition is generated due to TC. To investigate this, all the BSL days that occurred with the presence of TC over the WNP region have been further analyzed by compositing the BSL days in conjunction with the TC days in the WNP.

A total of 451 days of BSL occur during TC, while the other 178 days occur during non-TC. In terms of percentages, the BSL with the presence of TC represents nearly $72 \%$ of the total BSL days. Figure 9 shows the composite of $925-\mathrm{hPa}$ anomalous wind streamlines of BSL days during the presence of TCs from the year 1998 to 2018 (May-September). Generally, the anomalous cyclonic circulations (vortices) occurred significantly over the northern region of the Philippines during these periods, which indicated the TC genesis. These anomalous circulation cells intensified the monsoon westerly winds and extended them eastward. The active monsoon trough can significantly be observed throughout the period due to the occurrence of these anomalous cyclonic circulations. The anomalous cyclonic circulation tilts from the north (Figure 9a,b,d) to the south (Figure 9c,e), following the position of TC. However, only when the trough is close enough to the equatorial SCS, the number of BSL increases significantly (Figure 9c,e).

The distinctively stronger than normal westerly winds (indicate by blue to red shaded areas) during BSL are caused by the active monsoon trough in response to the presence of TC. The monsoon trough is established as a favorable region of TC genesis because it provides an environment of large vorticity [75]. Moreover, the presence of stronger westerly anomalies due to cyclogenesis lead to a more active monsoon trough [81]. The circulation cells from the cyclogenesis intensified the monsoon westerly winds and extended them eastward. Due to the Coriolis force, most of the WNP TCs propagated in a north-westward direction as they reached the SCS [80]. With a north-westward track, TC transports strong westerly winds to the SCS, which then triggers the eastward retreat of the WNPSH and the intrusion of the south-westerly winds from the southern hemisphere through Peninsular Malaysia and Borneo terrain [80]. These stronger westerly winds contribute to wind speed convergence in the SCS as the flows converge towards the center of the circulation cell in the Philippines region. At the same time, the south-westerly winds converged with these westerly winds, thus contributing to the development of an area of a very strong convergence region that is conducive for an MCS cloud type like BSL. 

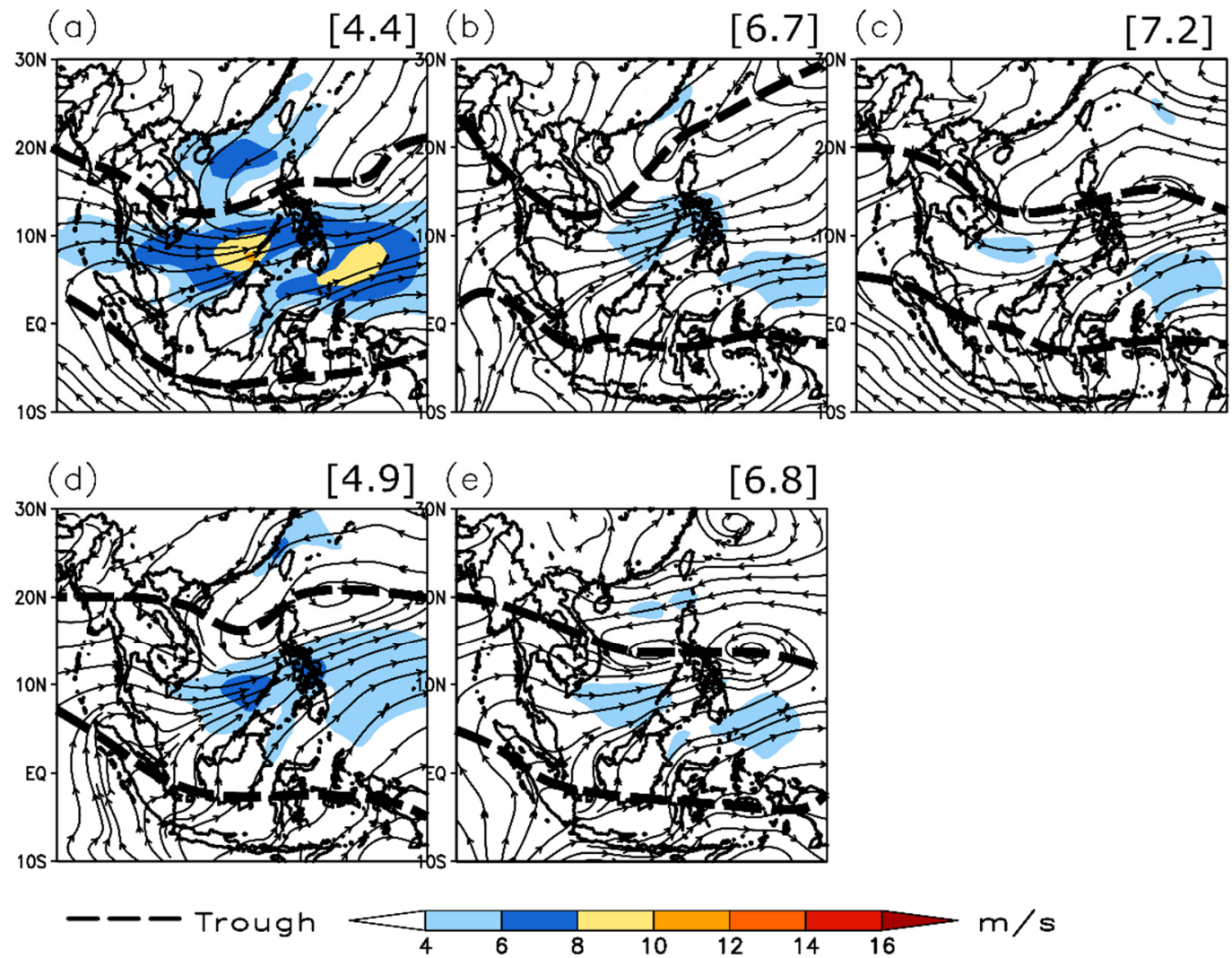

Figure 9. Composite of $925-\mathrm{hPa}$ anomalous wind streamline charts of all collected BSL days during the presence of TCs in (a) May, (b) June, (c) July, (d) August, and (e) September from the year 1998 to 2018. The average frequency (day) of BSL per month is indicated in the bracket at the upper corner of each panel. Blue to red shaded area indicates stronger wind speed, while monsoon trough is denoted by a black, thick-dashed line.

\subsection{The Relationship between ENSO and BSL}

El-Niño and La-Niña are the warm and cool phases of a recurring climate pattern across the tropical Pacific with the events tending to occur on an average of every 2 7 years [68]. The role of El-Niño and La-Niña in influencing the variability of rainfall and contributing to the extreme weather events in Malaysia is enormous [49,51,53,58,67,82]. Thus, this information is crucially important to understand the variation of BSL occurrence. Figure 10 shows a power spectral analysis of total annual frequency (day) of BSL from the year 1998 to 2018 providing information on the prominent periodicity of the BSL interannual variability. The result shows that the prominent frequencies occur mainly in 3-4- and 6-year time scales. The pronounced variations that occurred within the periods of 3 to 6 years are likely reflecting the influences of ENSO [68].

To further understand this situation, the correlation analysis between BSL days and the average SST anomalies $\left({ }^{\circ} \mathrm{C}\right)$ from preceding seasons, i.e., January-March, March-May, and May-July is represented in Figure 11a-c, respectively. The patterns depict a retreat La-Niña showing the weakening of negative SST anomalies. Negative (positive) correlation between BSL days and SST anomalies demonstrate more (less) BSL days in post La-Niña (post El-Niño) years. Therefore, from the analyses, it is revealed that the year to year variations of BSL frequency can be modulated by the ENSO. 


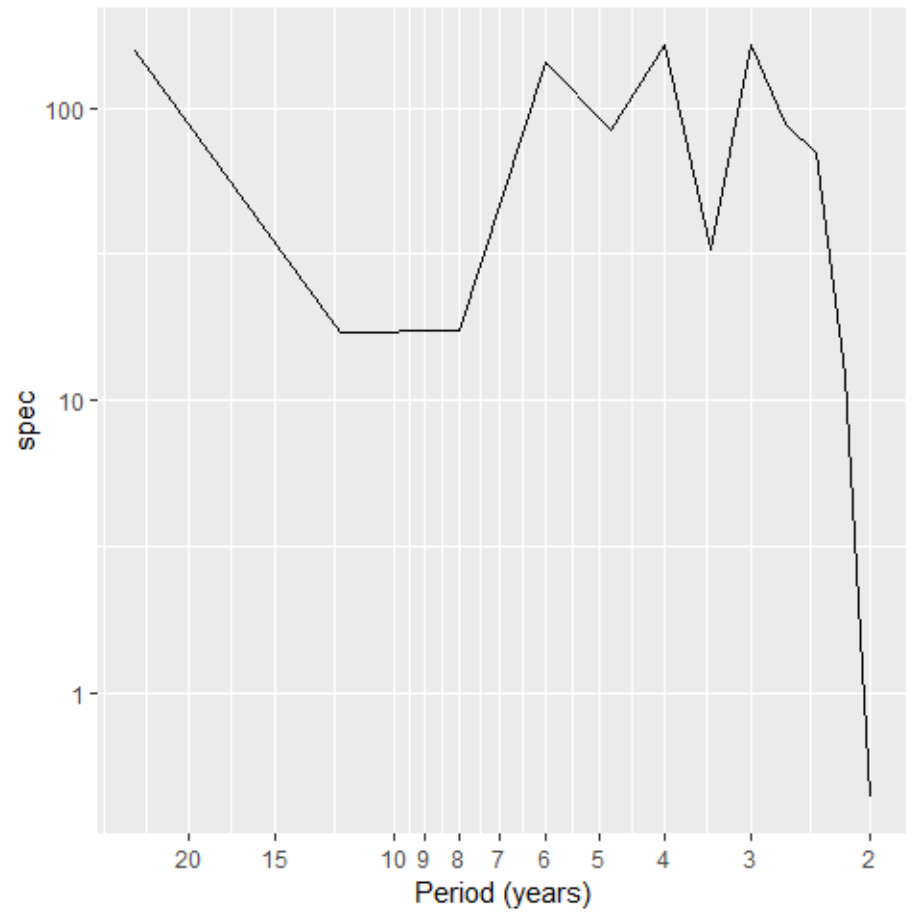

Figure 10. Power spectral analysis of total annual frequency (day) of BSL from the year 1998 to 2018.

(a)

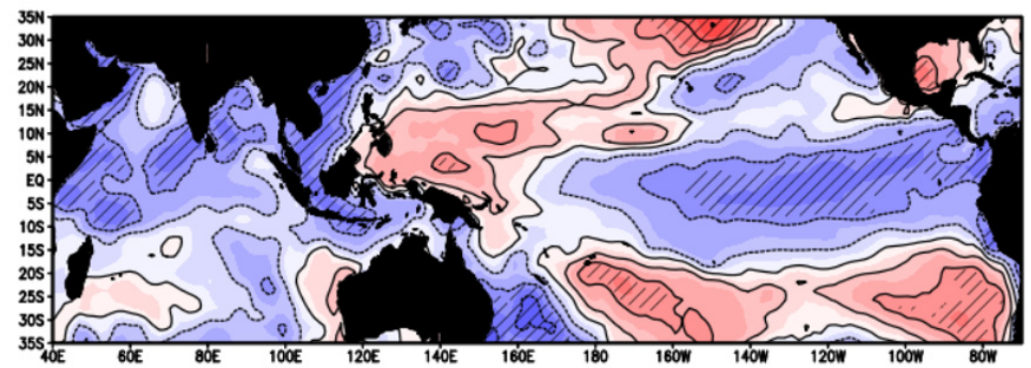

(b)

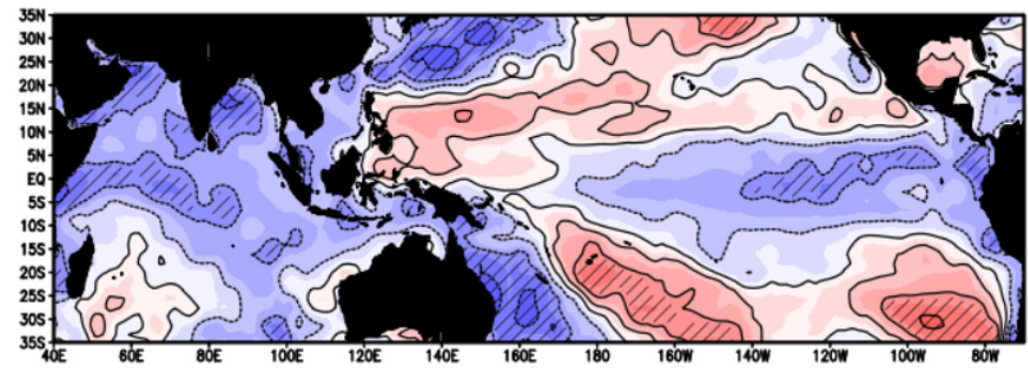

(c)

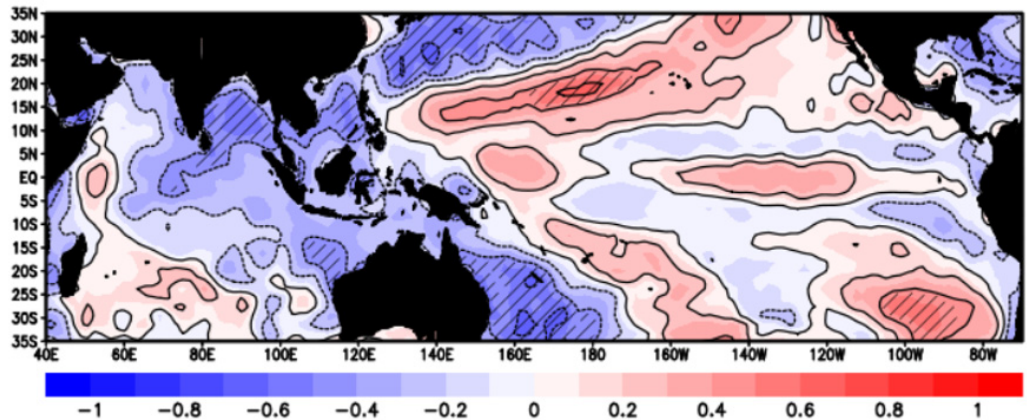

Figure 11. Correlation coefficient between BSL days and the SST anomalies $\left({ }^{\circ} \mathrm{C}\right)$ during (a) JanuaryMarch, (b) March-May, and (c) May-July. Areas significant at 0.05 level are hatched. 
To further demonstrate the BSL-ENSO correlations, Figure 12 shows the association between the monthly BSL frequencies and the preceding DJF Multivariate ENSO Index (MEI) yearly time-series. Here, the Kendall's rank correlation analysis is used and the significant is assessed with the Wilcoxon's rank sum test. The statistical test results are shown in Table 1.
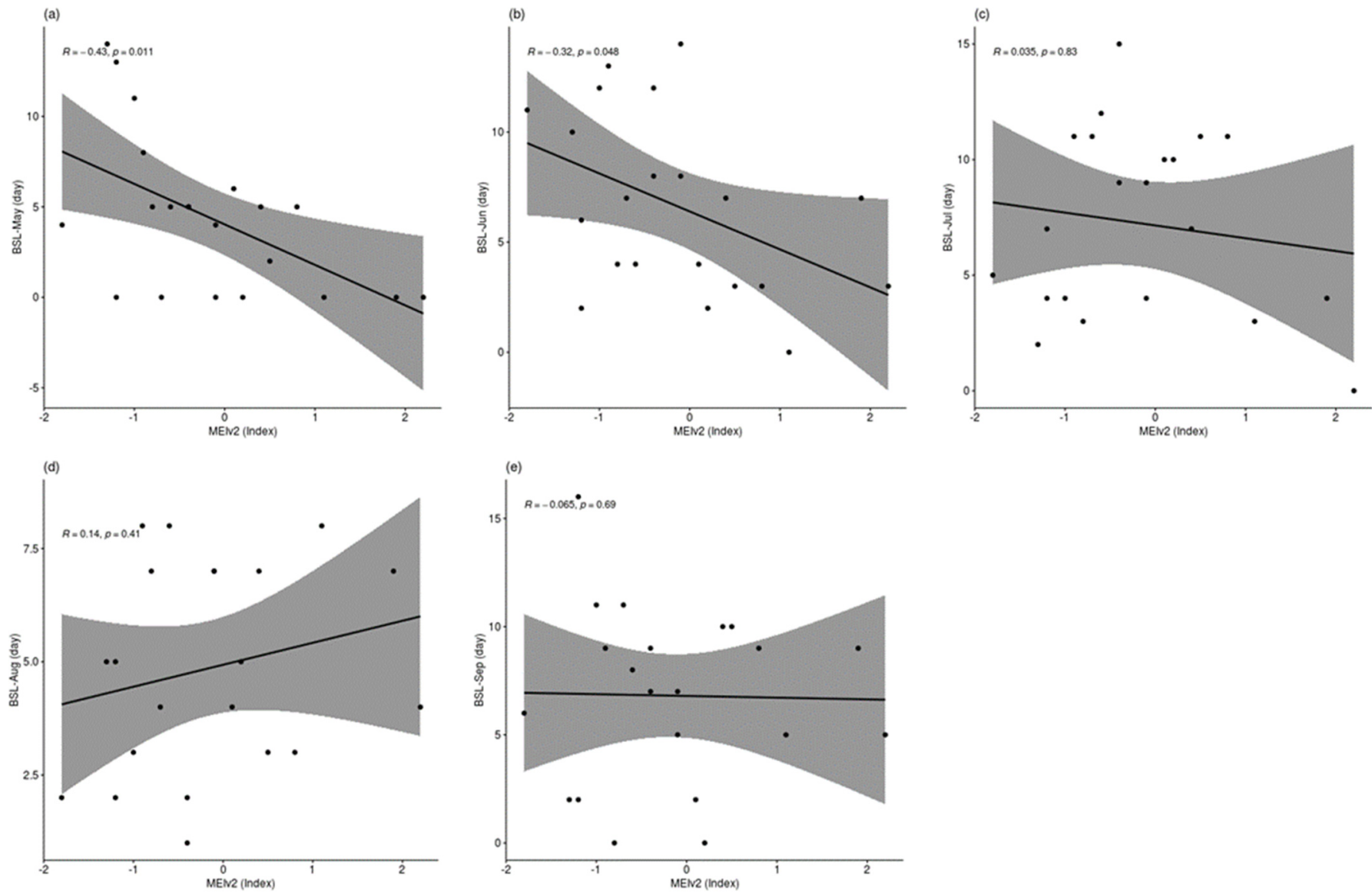

Figure 12. Scatterplots represent the correlation between monthly frequency of BSL (day) and the DJF MEI (a) May, (b) June, (c) July, (d) August, and (e) September. The slope in black-line denotes direction of the relationship (positive/negative).

Table 1. Correlation coefficient, Tau $(\tau)$ and $p$-values between the monthly frequency of BSL (day) and the DJF MEI.v2 index.

\begin{tabular}{cccccc}
\hline Value & May & June & July & August & September \\
\hline $\operatorname{Tau}(\tau)$ & -0.43 & -0.32 & -0.04 & 0.14 & -0.07 \\
\hline$p$ & 0.01 & 0.048 & 0.83 & 0.41 & 0.69 \\
\hline
\end{tabular}

The results show that there is a significant negative relationship between the frequency (day) of BSL with ENSO in May and June respectively. The strength of this relationship decreases drastically in July, August, and September. Consistent with Figure 11, the results suggest that frequency (days) of BSL increases during post La-Niña years and decreases during the post El-Niño years. The strength of the relationship from strong to weak depicts the weakening of ENSO influences towards the end of the season.

A slight different in the results during August (positive relationship) is likely influenced by the effect of active tropical cyclone (TC) formation in August, which is the period of peak TCs formation in the WNP region $[83,84]$. Several studies have shown that TCs are more likely to form closer to the Equator during the preceding El-Niño year $[48,85]$. 
The high tendency of TCs to form near the Equator could increase the formation of wind convergence zones in the SCS, which in turn could possibly increase the formation of BSLs in August during the El-Niño year.

In addition, as the higher probability of BSL occurs with the presence of TC, the possible effect of ENSO on interannual variability of TCs over the WNP should also be considered. Several studies have found that the number of annual TCs in WNP generally increases in the year after the La-Niña event, and tends to be below normal in the year after El-Niño [86]. However, due to warmer SST conditions, TCs became more intense and longer-lived during El-Niño but tended to become weaker and shorter-lived during La-Niña [75,87]. The formation of TCs also depend on the strength of El-Niño and La-Niña. Warmer SST and the availability of much moisture due to the moisture flux convergence over the Philippines and SCS during moderate La-Niña promotes the frequent formation of TCs in the WNP [67]. Besides, more TCs made landfalls over southern China, Philippines and Vietnam during La-Niña, conducive to more troughs develop near the equatorial SCS $[85,88]$. From the analysis and evaluation from previous studies, it can be considered that as the TCs actively develop in the WNP during La-Niña, especially during moderate La-Niña, thus showing that it may increase the chance for active BSL formation as well. Consequently, it can be said that in general, BSL days increase in La-Niña years, perhaps more often in moderate La-Niña.

\section{Conclusions}

The present study investigates the variations of BSL. Like other squall line systems in many parts of the world, BSL can lead to devastating effects for coastal activities such as fishing, oil rigs, aviation industries, and residential areas near the coastline. Currently, there is less study conducted on BSL and a lack of understanding of how this system is constructed. A greater understanding of BSL is necessary for the authorities to monitor and accurately forecast this kind of weather system. A better understanding of BSL processes is also crucial to protect commercial shipping, industries and property from weatherrelated losses.

Using the 3-hourly rainfall data of TRMM-3B42V7 from the year 1998 to 2018 (MaySeptember), 629 of BSL days were identified with monthly and annual averages of 6 and 30 days, respectively. July represented the highest number of squall line days. The results also revealed that BSL frequently initiated during midnight/predawn and terminated in the morning, and therefore this formation mechanism is likely influenced by the diurnal cycle [14]. In addition, the coastline direction of Borneo which is parallel to the low-level south-westerly prevailing winds enhance convective vertical development [15].

The ECMWF ERA-Interim daily wind data was used to understand the synoptic features during BSL formation. The analyses revealed that lower tropospheric wind convergence is the controlling factor of BSL formation. The position of the monsoon trough that is closer to the equatorial SCS with strong westerly component played important roles in creating this wind convergence region (directional and speed convergence). The results also show that the distinctively stronger than normal westerly winds during BSL are caused by the active monsoon trough, in response to the presence of TC. A total of 451 days of BSL occur during TC, which represents nearly $72 \%$ of the total BSL days. The monsoon trough is established as a favorable region of TC genesis because it provides an environment of large vorticity [75].

In response to the relationship between BSL interannual variability with ENSO, BSL frequency showed a significant increase during post La-Niña episode. As the TCs are actively developed in the WNP during La-Niña, especially during moderate La-Niña, thus showing that it may increase the chance for active BSL formation as well. Consequently, it can be said that in general, BSL days increase in post La-Niña years, perhaps more often in post moderate La-Niña.

Forecasting BSL is important yet difficult due to their rapid development and movement. This study is expected to have positive implications for real-time squall line fore- 
casting in Malaysia and contributes a good understanding of how BSL is formed. The present study suggests that lower tropospheric wind convergence (directional and speed convergence) is the controlling factor of BSL formation. According to [89], a strong sustained cold pool accompanied by vertical wind shear is conducive to the development of long-lived squall lines. This classic theory provides a reference to the initial thoughts about the formation mechanism. Thus, further investigation needs to be conducted to understand how vertical wind shear influences the strength of wind shear over the region. In addition, experiments using the high-resolution Numerical Prediction Model (NWP) are recommended to better comprehend how the diurnal cycle influences the strength of wind shear over the region.

As revealed by many studies, the influence of $\mathrm{MJO}$ in modulating the cloud and convection over the Maritime Continent is prominent. When MJO is in active phase in the Maritime Continent, it modulates anomalous westerly which may enhanced the formation of BSL. Given that the MJO has a high potential to influence the variability of BSL frequency, it is noteworthy to investigate the influence of MJO on the formation of BSL in future work. There is also an interest to extend the study to look into the potential for BSL formation during other seasons such as inter-monsoon and northeast monsoon seasons in the future.

Author Contributions: The work presented here was a collaboration between all authors. F.J.F.conceptualization, writing original draft, data curation, and analysis. N.A.N.-writing, review and editing, and preparing illustration. M.A.-writing, review, and editing. F.T.-writing, review, and editing. L.J.-writing, review, and editing, preparing illustration, project administration. All authors have read and agreed to the published version of the manuscript.

Funding: Part of the work is funded by Malaysia government fund FRGS/1/2020/WAB07/UKM/02/1. The first author was funded by the Malaysian government JPA scholarship when she conducted the research.

Institutional Review Board Statement: Not applicable.

Informed Consent Statement: Not applicable.

Data Availability Statement: Not applicable.

Acknowledgments: This research was funded by Malaysian government grant FRGS/1/2020/ WAB07/UKM/02/1. The appreciation also goes to the Research and Technical Development Division, Malaysian Meteorological Department (MMD) for the technical support in data collection and discussion on the manuscript.

Conflicts of Interest: The authors declare no known competing financial interest or personal relationship that influenced the work and result reported in this manuscript.

\section{References}

1. Wallace, J.M.; Hobbs, P.V.; McMurdie, L.; Houze, R.A., Jr. Atmospheric Science: An Introductory Survey, 2nd ed.; Elsevier: Amsterdam, The Netherlands, 2006; pp. 363-370.

2. Galvin, J.F.P. The weather and climate of the tropics: Part 8-Mesoscale weather systems. Weather 2009, 64, 32-38. [CrossRef]

3. Houze, R.A., Jr. Structure and dynamics of a tropical squall-line system. Mon. Weather Rev. 1977, 105, 1540-1567. [CrossRef]

4. Gamache, J.F.; Houze, R.A., Jr. Mesoscale air motion associated with a tropical squall line. Mon. Weather Rev. 1982, 110, 118-135. [CrossRef]

5. Houze, R.A., Jr.; Cetrone, J. Leading and trailing anvil clouds of West African squall lines. J. Atmos. Sci. 2011, 68, 1114-1123. [CrossRef]

6. Johnson, R.H.; Young, G.S. Heat and moisture budgets of tropical mesoscale anvil cloud. J. Atmos. Sci. 1983, 40, 2138-2147. [CrossRef]

7. Moncrieff, M.W.; Miller, M.J. The dynamics and simulation of tropical squall-lines. Quart. J. R. Met. Soc. 1976, 102, 373-394. [CrossRef]

8. Smith, W.P.; Gall, R.L. Tropical squall line of Arizona monsoon. Mon. Weather Rev. 1989, 117, 1553-1569. [CrossRef]

9. Tulich, S.N.; Kiladis, G.N. Squall lines and convectively coupled gravity waves in the tropics: Why do most cloud systems propagate westward? J. Atmos. Sci. 2012, 69, 2995-3012. [CrossRef]

10. Hidayat, A.M.; Efendi, U.; Rahmadini, H.N.; Nugraheni, I.R. The characteristics of squall line over Indonesia and its vicinity based on Himawari-8 satellite imagery and radar data interpretation. IOP Conf. Ser. Earth Environ. Sci. 2019, 303, 1-11. [CrossRef] 
11. Lo, J.C.-F.; Orton, T. The general features of tropical Sumatra Squalls. Weather 2016, 71, 175-178. [CrossRef]

12. Koh, I.-Y.; Teo, C.-K. Toward a mesoscale observation network in Southeast Asia. Am. Meteorol. Soc. 2009, 90, 481-488. [CrossRef]

13. Wu, P.; Hara, M.; Hamada, J.-i.; Yamanaka, M.D.; Kimura, F. Why a large amount of rain falls over the sea in the vicinity of western Sumatra Island during nighttime. J. Appl. Meteorol. Climatol. 2009, 48, 1345-1361. [CrossRef]

14. Yi, L.; Lim, H. Semi-Idealized COAMPS ${ }^{\circledR}$ Simulations of Sumatra Squall Lines: The Role of Boundary Forcing; Ip, W.-H., Chen, Y.-T., Eds.; World Scientific Publishing Co. Pte. Ltd.: Singapore, 2006; Volume 9, pp. 111-124.

15. Ichikawa, H.; Yasunari, T. Time- space characteristics of diurnal rainfall over Borneo and surrounding oceans as observed by TRMM-PR. J. Clim. 2006, 19, 1238-1260. [CrossRef]

16. Yasunari, T.; Kanamori, H.; Kuraji, K. Modulation of the diurnal cycle of rainfall associated with the MJO observed by a dense hourly rain gauge network at Sarawak, Borneo. J. Clim. 2013, 26, 4858-4875. [CrossRef]

17. Murakami, M. Analysis of deep convective activity over the western Pacific and Southeast Asia. Part I: Diurnal variation. $J$. Meteorol. Soc. Jpn. 1983, 61, 60-76. [CrossRef]

18. Wolff, D.B.; Nelkin, E.J.; Bolvin, D.T.; Huffman, G.J.; Adler, R.F.; Gu, G.; Hong, Y.; Bowman, K.P.; Stocker, E.F. The TRMM Multisatellite Precipitation Analysis (TMPA): Quasi-Global, Multiyear, Combined-Sensor Precipitation Estimates at Fine Scales; GESDISC, NASA: Greenbelt, MD, USA, 2007; Volume 8, pp. 38-55.

19. Rickenbach, T.M. Cloud-top evolution of tropical oceanic squall lines from radar reflectivity and infrared satellite data. Mon. Weather Rev. 1999, 127, 2951-2976. [CrossRef]

20. Chen, Y.; Ebert, E.E.; Walsh, K.J.E.; Davidson, N.E. Evaluation of TRMM 3B42 precipitation estimates of tropical cyclone rainfall using PACRAIN data. J. Geophys. Res. Atmos. 2013, 118, 2184-2196. [CrossRef]

21. Jirak, I.L.; Cotton, W.R.; Mcanelly, R.L. Satellite and radar survey of mesoscale convective system development. Mon. Weather Rev. 2003, 131, 2428-2449. [CrossRef]

22. Chokngamwong, R.; Chiu, L.S. Thailand daily rainfall and comparison with TRMM products. J. Hydrometeorol. 2008, 9, 256-266. [CrossRef]

23. As-syakur, A.R.; Tanaka, T.; Osawa, T.; Mahendra, M.S. Indonesian rainfall variability observation using TRMM multi-satellite data. Int. J. Remote Sens. 2013, 34, 7723-7738. [CrossRef]

24. Houze, R.A., Jr.; Rasmussen, K.L.; Zuluaga, M.D.; Brodzik, S.R. The variable nature of convection in the tropics and subtropics: A legacy of 16 years of the Tropical Rainfall Measuring Mission satellite. Rev. Geophys. 2015, 53, 994-1021. [CrossRef] [PubMed]

25. Mahmud, M.; Numata, S.; Matsuyama, H.; Hosaka, T.; Hashim, M. Assessment of effective seasonal downscaling of TRMM precipitation data in Peninsular Malaysia. Remote Sens. 2015, 7, 4092-4111. [CrossRef]

26. Tan, M.; Ibrahim, A.; Duan, Z.; Cracknell, A.; Chaplot, V. Evaluation of sixh high-resolution satellite and ground-based precipitation products over Malaysia. Remote Sens. 2015, 7, 1504-1528. [CrossRef]

27. Varikoden, H.; Samah, A.A.; Babu, C.A. Spatial and temporal characteristics of rain intensity in the peninsular Malaysia using TRMM rain rate. J. Hydrol. 2010, 387, 312-319. [CrossRef]

28. Ayoub, A.B.; Tangang, F.; Juneng, L.; Tan, M.L.; Chung, J.X. Evaluation of gridded precipitation datasets in Malaysia. Remote Sens. 2020, 12, 613. [CrossRef]

29. Klotter, D.; Nicholson, S.E.; Jackson, B. Mesoscale convective systems over Western Equatorial Africa and their relationship to large-scale circulation. Mon. Weather Rev. 2009, 137, 1272-1294. [CrossRef]

30. Jaramillo, L.; Poveda, G.; Mejía, J.F. Mesoscale convective systems and other precipitation features over the tropical Americas and surrounding seas as seen by TRMM. Int. J. Climatol. 2017, 37, 380-397. [CrossRef]

31. Maranan, M.; Fink, A.H.; Knippertz, P. Rainfall types over southern West Africa: Objective identification, climatology and synoptic environment. Q. J. R. Meteorol. Soc. 2018, 144, 1628-1648. [CrossRef]

32. Nesbitt, S.W.; Cifelli, R.; Rutledge, S.A. Storm morphology and rainfall characteristics of TRMM precipitation features. Mon. Weather Rev. 2006, 134, 2702-2721. [CrossRef]

33. Nunes, A.M.P.; Silva Dias, M.A.F.; Anselmo, E.M.; Morales, C.A. Severe convection features in the Amazon Basin: A TRMM-based 15-year evaluation. Front. Earth Sci. 2016, 4, 37. [CrossRef]

34. Xu, W. East Asian Summer Monsoon Precipitation Systems: Rainfall Characteristics, Storm Morphologies and Convective Properties. Ph.D. Thesis, The University of Utah, Salt Lake City, UT, USA, 2011.

35. Mori, S.; Hamada, J.-I.; Tauhid, Y.I.; Yamanaka, M.D.; Okamoto, N.; Murata, F.; Sakurai, N.; Hashiguchi, H.; Sribimawati, T. Diurnal Land-Sea Rainfall Peak Migration over Sumatera Island, Indonesian Maritime Continent, Observed by TRMM Satellite and Intensive Rawinsonde Soundings. Mon. Weather Rev. 2004, 132, 2021-2039. [CrossRef]

36. Fujita, M.; Kimura, F.; Yoshizaki, M. Morning Precipitation Peak over the Strait of Malacca under a Calm Condition. Mon. Weather Rev. 2010, 138, 1474-1486. [CrossRef]

37. Dee, D.P.; Uppala, S.M.; Simmons, A.J.; Berrisford, P.; Poli, P.; Kobayashi, S.; Andrae, U.; Balmaseda, M.A.; Balsamo, G.; Bauer, P.; et al. The ERA-Interim reanalysis: Configuration and performance of the data assimilation system. Q. J. R. Meteorol. Soc. 2011, 137, 553-597. [CrossRef]

38. Kalnay, E.; Kanamitsu, M.; Kistler, R.; Collins, W.; Deaven, D.; Gandin, L.; Iredell, M.; Saha, S.; White, G.; Woollen, J.; et al. The NCEP/NCAR 40-Year Reanalysis Project. Bull. Am. Meteorol. Soc. 1996, 77, 437-472. [CrossRef]

39. Ahmad, I.; Tang, D.; Wang, T.; Wang, M.; Wagan, B. Precipitation trends over time using Mann-Kendall and Spearman's rho tests in Swat River Basin, Pakistan. Adv. Meteorol. 2015, 2015, 1-15. [CrossRef] 
40. Hsu, P.-C.; Chu, P.-S.; Murakami, H.; Zhao, X. An abrupt decrease in the late-season typhoon activity over the Western North Pacific*. J. Clim. 2014, 27, 4296-4312. [CrossRef]

41. Kripalani, R.H.; Kulkarni, A. Rainfall variability over South-East Asia-connections with Indian Monsoon and ENSO extremes: New perspectives. Int. J. Climatol. 1997, 17, 1155-1168. [CrossRef]

42. Kundzewicz, Z.W.; Robson, A. Detecting Trend and Other Changes in Hydrological Data; WMO: Geneva, Switzerland, 2000.

43. Sulaiman, N.H.; Kamarudin, M.K.A.; Mustafa, A.D.; Amran, M.A.; Azaman, F.; Abidin, I.Z.; Hairoma, N. Trend analysis of Pahang River using non-parametric analysis Mann Kendall's trend test. Malays. J. Anal. Sci. 2015, 19, $1327-1334$.

44. Wu, L.; Wang, B.; Geng, S. Growing typhoon influence on east Asia. Geophys. Res. Lett. 2005, 32. [CrossRef]

45. Zhao, H.; Wu, L.; Zhou, W. Assessing the influence of the ENSO on tropical cyclone prevailing tracks in the western North Pacific. Adv. Atmos. Sci. 2010, 27, 1361-1371. [CrossRef]

46. Hamed, K.H. The distribution of Kendall's tau for testing the significance of cross-correlation in persistent data. Hydrol. Sci. J. 2011, 56, 841-853. [CrossRef]

47. Wang, B.; Luo, X.; Liu, J. How robust is the Asian precipitation-ENSO relationship during the industrial warming period (1901-2017)? J. Clim. 2020, 33, 2779-2792. [CrossRef]

48. Lin, I.I.; Camargo, S.J.; Patricola, C.M.; Boucharel, J.; Chand, S.; Klotzbach, P.; Chan, J.C.L.; Wang, B.; Chang, P.; Li, T.; et al ENSO and Tropical Cyclones. In El Niño Southern Oscillation in a Changing Climate, Geophysical Monograph, 1st ed.; Geophysical Monograph Series; John Wiley \& Sons, Inc.: Hoboken, NJ, USA, 2021; Volume 253, pp. 377-408.

49. Tangang, F.; Juneng, L. Mechanisms of Malaysian rainfall anomalies. J. Clim. 2004, 17, 7. [CrossRef]

50. Larkin, N.K. Global seasonal temperature and precipitation anomalies during El Niño autumn and winter. Geophys. Res. Lett. 2005, 32. [CrossRef]

51. Tangang, F.T.; Juneng, L.; Ahmad, S. Trend and interannual variability of temperature in Malaysia: 1961-2002. Theor. Appl. Climatol. 2006, 89, 127-141. [CrossRef]

52. Zhou, L.-T.; Tam, C.-Y.; Zhou, W.; Chan, J.C.L. Influence of South China Sea SST and the ENSO on winter rainfall over south China. Adv. Atmos. Sci. 2010, 27, 832-844. [CrossRef]

53. Wong, C.; Liew, J.; Yusop, Z.; Ismail, T.; Venneker, R.; Uhlenbrook, S. Rainfall characteristics and regionalization in Peninsular Malaysia based on a high resolution gridded data set. Water 2016, 8, 500. [CrossRef]

54. Santoso, A.; McPhaden, M.J.; Cai, W. The defining characteristics of ENSO extremes and the strong 2015/2016 El Niño. Rev. Geophys. 2017, 55, 1079-1129. [CrossRef]

55. Supari; Tangang, F.; Juneng, L.; Aldrian, E. Observed changes in extreme temperature and precipitation over Indonesia. Int. J. Climatol. 2017, 37, 1979-1997. [CrossRef]

56. Ren, H.-L.; Lu, B.; Wan, J.; Tian, B.; Zhang, P. Identification standard for ENSO events and its application to climate monitoring and prediction in China. J. Meteorol. Res. 2019, 32, 923-936. [CrossRef]

57. Sazib, N.; Mladenova, L.E.; Bolten, J.D. Assessing the impact of ENSO on agriculture over Africa using earth observation data. Front. Sustain. Food Syst. 2020, 4, 188. [CrossRef]

58. Juneng, L.; Tangang, F.T. Evolution of ENSO-related rainfall anomalies in Southeast Asia region and its relationship with atmosphere-ocean variations in Indo-Pacific sector. Clim. Dyn. 2005, 25, 337-350. [CrossRef]

59. $\mathrm{Wu}, \mathrm{P}$.; Yamanaka, M.D.; Matsumoto, J. The formation of nocturnal rainfall offshore from convection over western Kalimantan (Borneo) Island. J. Meteorol. Soc. Jpn. 2008, 86A, 187-203. [CrossRef]

60. Wu, P.; Hamada, J.-I.; Yamanaka, M.D.; Matsumoto, J.; Hara, M. The impact of orographically-induced gravity waves on the diurnal cycle of rainfall over southeast Kalimantan Island. Atmos. Ocean. Sci. Lett. 2015, 2, 35-39. [CrossRef]

61. Wang, S.; Sobel, A.H. Factors controlling rain on small tropical islands: Diurnal cycle, large-scale wind speed, and topography. J. Atmos. Sci. 2017, 74, 3515-3532. [CrossRef]

62. Robertson, A.W.; Qian, J.-H.; Moron, V. Interactions among ENSO, the monsoon, and diurnal cycle in rainfall variability over Java, Indonesia. J. Atmos. Sci. 2010, 67, 3509-3524. [CrossRef]

63. Qian, J.-H.; Robertson, A.W.; Moron, V. Diurnal cycle in different weather regimes and rainfall variability over Borneo associated with ENSO. J. Clim. 2013, 26, 1772-1790. [CrossRef]

64. Bidin, K.; Chappell, N.A. Characteristics of rain events at an inland locality in northeastern Borneo, Malaysia. Hydrol. Processes 2006, 20, 3835-3850. [CrossRef]

65. Alfahmi, F.; Boer, R.; Hidayat, R.; Perdinan; Sopaheluwakan, A. The impact of concave coastline on rainfall offshore distribution over Indonesian Maritime Continent. Sci. World J. 2019, 2019, 6839012. [CrossRef]

66. Qian, J.-H. Why Precipitation Is Mostly Concentrated over Islands in the Maritime Continent. J. Atmos. Sci. 2008, 65, 1428-1441. [CrossRef]

67. Tangang, F.; Farzanmanesh, R.; Mirzaei, A.; Supari; Salimun, E.; Jamaluddin, A.F.; Juneng, L. Characteristics of precipitation extremes in Malaysia associated with El Niño and La Niña events. Int. J. Climatol. 2017, 37, 696-716. [CrossRef]

68. Scaife, A.; Guilyardi, E.; Cain, M.; Gilbert, A. What is the El Niño-Southern Oscillation? Weather 2019, 74, 250-251. [CrossRef]

69. Cheang, B.k. Interannual variability of monsoons in Malaysia and its relationship with ENSO. Proc. Indian Acad. Sci.-Earth Planet. Sci. 1993, 102, 219-239. [CrossRef]

70. Chang, C.P.; Harr, P.A.; Chen, H.-J. Synoptic disturbances over the equatorial South China Sea and western maritime continent during boreal winter. Mon. Weather Rev. 2005, 133, 489-503. [CrossRef] 
71. Li, T.; Wang, B.; Wu, B.; Zhou, T.; Chang, C.-P.; Zhang, R. Theories on formation of an anomalous anticyclone in western North Pacific during El Niño: A review. J. Meteorol. Res. 2018, 31, 987-1006. [CrossRef]

72. Wang, B.; LinHo; Zhang, Y.; Lu, M.-M. Definition of South China Sea monsoon onset and commencement of the east Asia summer monsoon. J. Clim. 2004, 17, 699-710. [CrossRef]

73. Klüpfel, V.; Kalthoff, N.; Gantner, L.; Taylor, C.M. Convergence zones and their impact on the initiation of a mesoscale convective system in West Africa. Q. J. R. Meteorol. Soc. 2012, 138, 950-963. [CrossRef]

74. Wang, B. The Asian Monsoon; Springer: Chichester, UK, 2006.

75. Chen, T.-C.; Wang, S.-Y.; Yen, M.-C. Interannual variation of the tropical cyclone activity over the western north Pacific. J. Clim. 2006, 19, 5709-5720. [CrossRef]

76. Vollaro, D.; Molinari, J. What Percentage of Western North Pacific Tropical Cyclones Form within the Monsoon Trough? Mon. Weather Rev. 2013, 141, 499-505. [CrossRef]

77. Neumann, C.J. Global Guide to Tropical Cyclone Forecasting; World Meteorological Organization: Geneva, Switzerland, 2017; Volume WMO-1194.

78. Gao, S.; Zhu, L.; Zhang, W.; Shen, X. Western North Pacific tropical cyclone activity in 2018: A season of extremes. Sci. Rep. 2020, 10, 5610. [CrossRef]

79. Zhan, R.; Wang, Y.; Ying, M. Seasonal forecasts of tropical cyclone activity over the western north Pacific: A review. Trop. Cyclone Res. Rev. 2012, 1, 307-324. [CrossRef]

80. Huangfu, J.; Huang, R.; Chen, W. Relationship between the South China Sea summer monsoon onset and tropical cyclone genesis over the western North Pacific. Int. J. Climatol. 2017, 37, 5206-5210. [CrossRef]

81. Cheang, B.-K.; Tan, H.-V. Some aspects of the summer monsoon in South-East Asia May to September 1986. Aust. Meteorol. Mag. 1988, 36, 227-233.

82. Tangang, F.T.; Liew, J.; Salimun, E.; Jui, L.L. Climate change and variability over Malaysia: Gaps in science and research information. Sains Malays. 2012, 41, 1355-1366.

83. Yang, L.; Wang, X.; Huang, K.; Wang, D. Anomalous tropical cyclone activity in the western north Pacific in August 2014. Bull. Am. Meteorol. Soc. 2015, 96, S120-S125. [CrossRef]

84. Zhang, W.-Z.; Lin, S.; Jiang, X.-M. Influence of tropical cyclones in the western north Pacific. In Recent Developments in Tropical Cyclone Dynamics, Prediction, and Detection; Intech: London, UK, 2016.

85. Zuki, Z.M.; Lupo, A.R. Interannual variability of tropical cyclone activity in the southern South China Sea. J. Geophys. Res. 2008, 113, 14. [CrossRef]

86. Chan, J.C.L. Tropical cyclone activity over the western north Pacific associated with El-Nino and La-Nina events. Jounal Clim. 2000, 13, 2960-2972. [CrossRef]

87. Camargo, S.J.; Sobel, A.H. Western north Pacific tropical cyclone intensity and ENSO. J. Clim. 2005, 18, 2996-3006. [CrossRef]

88. Saunders, M.A.; Chandler, R.E.; Merchant, C.J.; Roberts, F.P. Atlantic hurricanes and NW Pacific typhoons: ENSO spatial impacts on occurrence and landfall. Geophys. Res. Lett. 2000, 27, 1147-1150. [CrossRef]

89. Rotunno, R.; Klemp, J.B.; Weisman, M.L. A theory of strong, long-lived squall lines. J. Atmos. Sci. 1988, 45, 463-485. [CrossRef] 